\title{
Life cycle analyses of organic photovoltaics: a review
}

Cite this: Energy Environ. Sci., 2013, 6, 3136

Received 5th August 2013

Accepted 13th September 2013

DOI: 10.1039/c3ee42653j

www.rsc.org/ees

\author{
Sebastien Lizin, ${ }^{* a}$ Steven Van Passel, ${ }^{a}$ Ellen De Schepper, ${ }^{a}$ Wouter Maes, ${ }^{b}$ \\ Laurence Lutsen, ${ }^{\mathrm{b}}$ Jean Manca ${ }^{\mathrm{b}}$ and Dirk Vanderzande ${ }^{\mathrm{b}}$
}

This paper reviews the available life cycle analysis (LCA) literature on organic photovoltaics (OPVs). This branch of OPV research has focused on the environmental impact of single-junction bulk heterojunction polymer solar cells using a $\mathrm{P} 3 \mathrm{HT} / \mathrm{PC}_{60} \mathrm{BM}$ active layer blend processed on semi-industrial pilot lines in ambient surroundings. The environmental impact was found to be strongly decreasing through continuous innovation of the manufacturing procedures. The current top performing cell regarding environmental performance has a cumulative energy demand of $37.58 \mathrm{MJ}_{\mathrm{p}} \mathrm{m}^{-2}$ and an energy payback time in the order of months for cells having $2 \%$ efficiency, thereby rendering OPV cells one of the best performing PV technologies from an environmental point of view. Nevertheless, we find that LCA literature is lagging behind on the main body of OPV literature due to the lack of readily available input data. Still, LCA research has led us to believe that in the quest for higher efficiencies, environmental sustainability is being disregarded on the materials' side. Hence, we advise the scientific community to take the progress made on environmental sustainability aspects of OPV preparations into account not only because standard procedures put a bigger strain on the environment, but also because these methods may not be transferrable to an industrial process. Consequently, we recommend policy makers to subsidize research that bridges the gaps between fundamental materials research, stability, and scalability given that these constraints have to be fulfilled simultaneously if OPVs are ever to be successful on the market. Additionally, environmental sustainability will have to keep on being monitored to steer future developments in the right direction.

\section{Broader context}

Organic photovoltaics (OPVs) have attracted considerable interest due to their potential to be flexible, solution coatable, low cost, low weight, semi-transparent, and easily integratable into different applications. Consequently, many commercialization routes (e.g. portable chargers for consumer electronics, developing world applications, automotive applications, building integrated photovoltaics, etc.) have been identified based on judgments about the evolution in performance on the triangle of efficiency, lifetime, and cost. In case these projections would turn into reality, the wide scale deployment of OPV devices may imply unforeseen negative environmental impacts, if not properly assessed ex-ante. To this end, life cycle analysis (LCA) has been identified as an appropriate tool. LCA is a quantitative product-related assessment technique intended to compare and analyze both the energy use and environmental impacts associated with a product over its full life-cycle, including the following stages: (1) acquisition of raw materials, (2) materials processing/manufacturing, (3) use, and (4) end-of-life, with optional additional transport stages in between. Its results allow steering product and process development in a more sustainable direction. We provide a review of all available LCA literature on OPVs and find their environmental impact to be strongly decreasing through continuous innovation of the manufacturing procedures.

\section{Sustainability and solar cells}

Sustainability has become a global issue through the increasing general awareness of the limits to the availability of nonrenewable resources and to nature's ability to assimilate wastes, which is one of the key regulating ecosystem services. ${ }^{1}$ Bearing this thought - among others ${ }^{2}$ - in mind, the European

${ }^{a}$ Centre for Environmental Sciences (CMK), Hasselt University, Agoralaan, Building D, B-3590 Diepenbeek, Belgium.E-mail: sebastien.lizin@uhasselt.be; steven.vanpassel@ uhasselt.be; ellen.deschepper@uhasselt.be; Tel: +32 11268696

${ }^{b}$ Institute for Materials Research (IMO-IMOMEC), and IMOMEC Assoc. Lab., IMEC, Hasselt University, Agoralaan, Building D, B-3590 Diepenbeek, Belgium. E-mail: wouter.maes@uhasselt.be; laurence.lutsen@uhasselt.be; jean.manca@uhasselt.be; dirk.vanderzande@uhasselt.be
Commission has put in place the 20-20-20 targets to deal with energy-related environmental issues. ${ }^{3}$ These targets aim at a $20 \%$ reduction in European Union (EU) greenhouse gas emissions from 1990 levels, a rise in the share of EU energy consumption produced from renewable resources to $20 \%$, and a $20 \%$ improvement in the EU's energy efficiency. Such legislation has motivated national governments to both subsidize the dissemination and fund the R\&D of renewable energy technologies, such as different generations of photovoltaic (PV) cells. Through their renewable nature solar energy systems should inherently provide significant environmental benefits in comparison to the conventional energy sources they displace, thus contributing to the sustainable development of human activities. $^{4}$ 
Photovoltaic cells can be categorized into first, second, and third generation, being (1) crystalline silicon solar cells, (2) thin film solar cells, and (3) new PV technology (a less defined range of advanced technologies overcoming the Shockley-Queisser limit). ${ }^{5}$ The polymer and molecular organic photovoltaic (OPV) cells belong to the second category. $\uparrow$ Global interest in developing these types of OPV cells mainly stems from their potential to be flexible, solution coatable, low cost, low weight, semi-transparent, and easily integratable into different applications. ${ }^{6-11}$ Commercialization routes for devices incorporating such cells can be found in the literature. ${ }^{7,12-15}$ These routes are mainly based on judgments about the evolution in performance on the triangle of efficiency, lifetime, and cost alongside the technology's development. In case these projections would turn into reality, the wide scale deployment of OPV devices may imply unforeseen negative environmental impacts, if not properly assessed ex-ante. ${ }^{\mathbf{1 6}}$ Ideally, informed decisions should be taken at the product design stage, signaling that life cycle, ecotoxicity, and health risk assessments of the product's constituents should have been completed prior to all life cycle stages.

From the results of a patent count analysis covering the period 1998-2011, ${ }^{17}$ OPV cells were found to be residing in the fluid technology development phase, implying that the main focus resided on product innovation rather than process innovation. For OPVs, we defined product innovations as those actions of changes in the materials and in the device architecture aiming at higher performance (mostly efficiency), while process innovations are those measures aiming at a lower cost, both monetary and environmental. These concepts are adapted from the 'Dynamics of Innovation' theory, which was originally proposed by Utterback and Abernathy. ${ }^{18}$ Progress on the product innovation field was found to be exponential, while process innovation was not so well documented. ${ }^{17}$ Nevertheless, there have been upscaling demonstrator projects ${ }^{19-22}$ and pioneers exist that actively distribute their films, allowing industry partners in the areas of building materials, automotive, consumer devices and electronics to start developing integrated products. ${ }^{23}$ Accordingly, organic solar cells' future constitution and manufacturing process are still relatively open to change. Furthermore, scholars are increasingly aware of the fact that it should be considerate of the environment. For instance, F. Krebs ${ }^{24}$ describes the ideal process for polymer solar cells as: "Involving solution processing of all layers on flexible substrates by the combination of as few coating and printing steps as possible, being free from costly indium, toxic solvents and chemicals, and resulting in a final product with a low environmental impact and a high degree of recyclability".

How should one assess a product's environmental sustainability? Taking a glance at the framework for sustainability assessment tools by Ness et al.,${ }^{25}$ life cycle analysis (LCA) seems an appropriate tool. ${ }^{26}$ An LCA is a quantitative product-related assessment technique intended to compare and analyze both the energy use and environmental impacts associated with a product over its full life-cycle, including the following stages: (1)

$\dagger$ Dye sensitized solar cells are disregarded in this work since they are mainly based on inorganic semiconductors. acquisition of raw materials, (2) materials processing/ manufacturing, (3) use, and (4) end-of-life, with optional additional transport stages in between. ${ }^{27}$ However, as retrieving all upstream and downstream information about environmental impacts would require an enormous effort, the traditional approach is to downsize the scope. This involves selecting which life cycle stages to investigate in order to reduce LCA costs. Fig. 1 represents the scope of this review and simultaneously the scope of its supporting literature. Therefore, amongst others, the impacts from the use phase, the end-of-life phase, transport stages from and to the manufacturing gate, and the manufacturing equipment and facility used in processing OPV devices have been omitted. Such truncation of resource requirements or pollutant releases in upstream or downstream stages of the supply chain, performed on process-based or site-specific data used such as the specific materials made by the group conducting the LCA or firm selling the commercialized material, leads to the underestimation of environmental impacts. Such errors may be reduced by using a hybrid LCI method instead of a process-based one. ${ }^{28-30}$ At the same time, the researcher is rather free to select the environmental impact categoriest that will be characterized by the collected data. Current guidelines do not specify a minimum number of impact categories to be included or a preferred methodology, but suggest typical impact categories.

The manufacturing of PV cells should certainly be low on greenhouse gas emissions, as $\mathrm{CO}_{2}$ equivalent emissions are the energy sector's main environmental concern. ${ }^{31}$ Consequently, LCAs on PV systems have traditionally focused on energy use and the related greenhouse gas emissions. ${ }^{27}$ The cumulative fossil energy demand $\left(\mathrm{C}_{\mathrm{f}} \mathrm{ED}\right)$ has been shown to be well correlated with most other environmental indicators $\S$ for the product category of energy production. It may therefore serve as a screening indicator and is particularly useful in case of absence and uncertainty surrounding life cycle inventory (LCI) data. $^{32}$ Therefore, the environmental sustainability of OPV devices is measured in terms of cumulative energy demand (CED), $\uparrow$ the energy payback time (EPBT), and the greenhouse gas (GHG) emission factor. The CED represents the primary energy demand required during the stages included in the study's scope. The EPBT measures the time needed to generate the equivalent amount of energy consumed during the stages included in the study's scope. The GHG emission factor $\left(\mathrm{CO}_{2} \mathrm{eq}\right.$. $\mathrm{kW}^{-1} \mathrm{~h}^{-1}$ ) indicates the amount of emission of embodied $\mathrm{CO}_{2}$ equivalents during the stages included in the study's scope per kilowatt-hour of produced electricity over the device's lifetime. In other words, it denotes how many greenhouse gases would be emitted by the device per unit of electricity that is generated.

Even though the scholars who shape the development of OPV cells are increasingly aware of the importance of environmental

\footnotetext{
\$E.g.: global warming, resource depletion, acidification, eutrophication, tropospheric ozone formation, ozone depletion, human toxicity, ecotoxicity, land use, etc.

$\S$ Global warming, resource depletion, acidification, eutrophication, tropospheric ozone formation, ozone depletion, and human toxicity (explained variance between 46 and 100\%).

I With several energy mixes being used.
} 


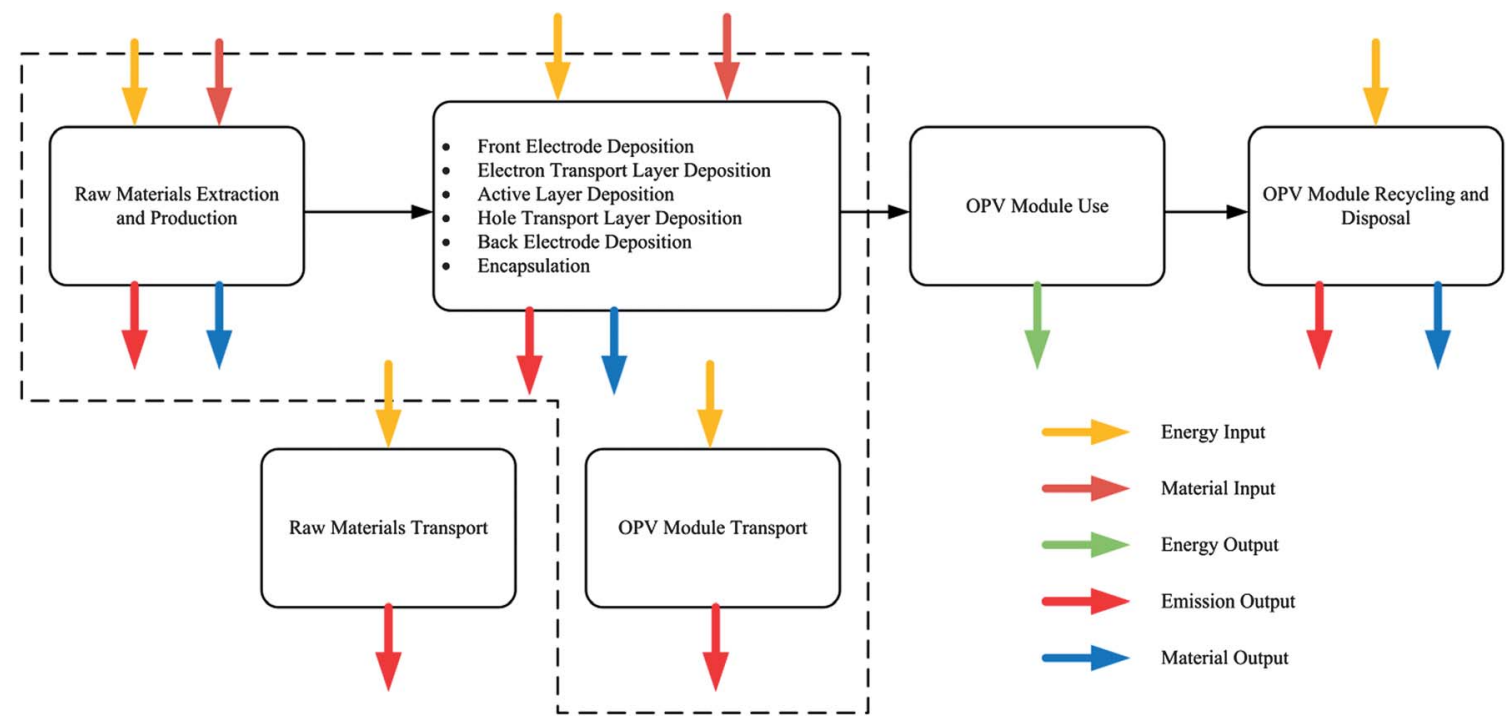

Fig. 1 OPV life cycle analysis scope definition. ${ }^{58}$

sustainability, we question whether the supporting LCA studies are able to keep up with the high pace of product development. Consequently, we draw an environmental profile from the available peer-reviewed journal LCA literature and highlight and discuss the possibilities for future improvement of OPVs' environmental performance. To find such literature, a systematic approach is advisable, amongst which keyword searches using Boolean logic are a commonly used method. ${ }^{33}$ To this end the Web of Science, SciFinder and Google Scholar databases were used covering the time period 1999 - the year in which OPV research publications started to grow exponentially ${ }^{34}$ - to 2013.

In Section 1 the environmental concern surrounding the development of OPVs has been introduced. In Section 2 we provide a brief insight into the LCA methodology. Section 3 describes the evolution of the environmental profile of OPV solar cells. The literature is divided into themes, i.e. the respective study goals, and is presented chronologically in line with the technology's development. The fourth segment discusses the results and suggests routes for further improvement of the environmental sustainability of OPVs. The final section holds the main findings of our work.

\section{Life cycle analysis methodology}

The general steps in the LCA framework are standardized according to the ISO 14000 series. ${ }^{35-38}$ They include: (1) goal and scope definition (see Fig. 1), (2) inventory analysis which quantifies the material inputs, the energy inputs, and the environmental releases over the specified life-cycle stages, (3) impact assessment which cumulates flows into the impact categories under revision, and (4) interpretation of the results. Conclusions should allow identifying where environmental improvement can be realized in product and process development. Additionally, LCAs have been used to compare different renewable energy technologies, but note that the degree of true comparison varies with scope similarity and requires methodological transparency.
Indeed, although LCA is a standardized method, it still leaves the practitioner with a range of choices that affect its outcome. To regulate the LCA routine further, methodological guidelines on the LCA of photovoltaic electricity have been drafted by Fthenakis et al. ${ }^{39}$ They suggest that at least the following parameters should be reported to increase the results' transparency: (1) the goal of the study and the functional unit, (2) the system boundaries, (3) the LCA method, tool and databases used (if data are not processbased), (4) on-plane irradiation level and location, (5) module rate efficiency, (6) system performance ratio (PR), (7) expected lifetime and degradation rate for the PV module and the balance of system (BOS), (8) the place of production, (9) the type of system (e.g. roof top or ground mounted), (10) the time frame of the data, (11) the representativeness of the study (if data are from a pilot-scale), (12) assumptions for the production of major inputs, (13) the name of the entity commissioning the study (if applicable) and (14) the calculation method of the EPBT. Based on these guidelines, it is our opinion that OPV LCA literature has done a fair job in increasing transparency. Only the degradation rate and LCA method specification are omitted in most studies. Additionally, the calculation of EBPT is not as extended as that given in the guidelines, but is mostly consistent within OPV LCA literature.

Nevertheless, for OPV solar cells the task of conducting an LCA requires enormous efforts given the lack of readily available inventory data in the commonly used LCA databases, while little generality may be gained as processing techniques and manufacturing methods are not yet standardized ${ }^{40}$ In view of this lack, studies adopt data from: (1) laboratory scale or pilot line scale processes, (2) literature (on similar or previously published processes), and (3) own estimations using default values and stoichiometric reactions according to previously published guidelines for uninventoried chemicals. The obtained results thus represent an uncertain, rather pessimistic benchmark for fully scaled-up production, but nevertheless they have their value by allowing us to assess the technology's environmental progress. 
Table 1 Overview of available LCA literature regarding OPVs

\begin{tabular}{|c|c|}
\hline Source & Topic \\
\hline 57 & $\begin{array}{l}\text { Laboratory production of standard } \\
\text { BHJ P3HT/PCBM polymer PVs on a } \\
\text { glass substrate, all framed and with } \\
\text { balance of system, and PET } \\
\text { substrates, without frames and BOS }\end{array}$ \\
\hline 56 & $\begin{array}{c}\text { Laboratory production of standard } \\
\text { BHJ P3HT/PCBM polymer PVs on a } \\
\text { glass substrate }\end{array}$ \\
\hline 60 & $\begin{array}{l}\text { Semi-industrial manufacturing of } \\
\text { inverted BHJ P3HT/PCBM polymer } \\
\text { PVs on a PET substrate under } \\
\text { ambient conditions, except for ITO } \\
\text { application, called ProcessOne }\end{array}$ \\
\hline 61 & $\begin{array}{l}\text { Solution processable ITO-free } \\
\text { transparent electrodes }\end{array}$ \\
\hline
\end{tabular}

62 Semi-industrial manufacturing of ITO-free inverted BHJ P3HT/PCBM polymer PVs or HIFLEX modules

Semi-industrial manufacturing of inverted BHJ P3HT/PCBM polymer PVs using various routes, not containing ITO

\footnotetext{
Calculation of life cycle embodied materials, both polymers and small molecules, energy and process energy for 26 new material combinations
}

Sensitivity analysis of GHG emissions and EPBT for a semiindustrial production of inverted BHJ P3HT/PCBM polymer PVs for 3 scenarios
Semi-industrial manufacturing of inverted BHJ $\mathrm{P} 3 \mathrm{HT} / \mathrm{PCBM}$ polymer solar modules by 3 different routes

(SSE, PSE, SFE) with different

encapsulation and adhesives

Scenario analysis (current, mid, and long term) of EPBT and GHG emission factor for Process $\mathrm{H}$ based OPV devices

Goal

Life cycle inventory data

Estimations based on the literature,

Prospective comparison:

- Between rigid and flexible polymer PV system

- With other commercially available PV systems

Prospective comparison:

- Between the extrapolation of industrial OPV production and industrial production of other PVs

\section{Retrospective comparison:}

- Between flexible polymer PVs and other organic and hybrid technologies

\section{Retrospective comparison:}

- Between ITO and high conductivity PEDOT:PSS, silver grid in PEDOT:PSS, silver nanowires and single walled carbon nanotubes

Retrospective comparison: - Between ITO-based and ITO-free module having an $\mathrm{Al} / \mathrm{Cr}$ electrode

\section{Retrospective comparison:}

- Between ProcessOne and alternative routes

Prospective comparison:

- After implementing feasible and challenging improvements upon process $\mathrm{H}$

\section{Retrospective comparison:}

- Between old and new polymer PV devices and between OPVs and inorganic PVs

\section{Prospective comparison:}

- Verify the impact on the EPBT and the GHG emission factor of dynamic analysis on OPVs and compare the results with other PV technologies

\section{Retrospective comparison:}

- Compare CED and EPBT for all routes

\section{Prospective comparison:}

- Verify the impact on the EPBT and the GHG emission factor of dynamic analysis on OPVs and compare the results with other PV technologies, while also forecasting their progress
Estimations based on the literature, manufacturers and own experience

Estimations based on the literature, LCI databases, manufacturers and own experience

Uses data from ref. 60, replaces ITO with the impact of alternative electrodes found in the literature

Uses data from ref. 55, 56 and 60 and own estimates for $\mathrm{Al} / \mathrm{Cr}$ deposition

Uses data from the literature, LCI databases and own estimations

Estimations based on information from the literature, LCI databases and own estimations

Data based on ref. 59

Estimations based on information from previous literature, databases, manufacturers and own estimations

Uses data from ref. 59 for OPVs and from the literature for other PV technologies 
Two main types of LCA models have been distinguished in the literature, being: (1) attributional and (2) consequential LCA. Attributional LCAs are defined by their focus on describing the environmentally relevant physical flows to and from a life cycle and its subsystems by means of average data. On the other hand, consequential LCAs are defined by their aim to describe how environmentally relevant flows will change in response to possible decisions implying changes in product demand by means of marginal data. ${ }^{41}$ A key reference detailing the difference between attributional and consequential LCAs is found in the work of Thomassen et al. on the environmental impact of milk production. ${ }^{42}$ They argue that the difference in both approaches is strongly nested in (1) the way to deal with allocation problems and (2) the choice of data. In the attributional LCA of milk production, mass and economic value based allocation rules were used to distribute the impacts between the main product (milk) and the co-product (animals). A review of allocation rules in ISO 14041 divides allocation rules into physical (e.g. mass, energy, exergy), economic value based ( $€$ ), or open-loop recycling based decision rules. ${ }^{43}$ Additionally, average data were used to represent the milk production system. In the consequential LCA of additional milk production, the production system was expanded because milk is associated with the co-product beef. The avoided burden of additional beef was found in the avoided production of beef and pork. Additionally, marginal data are used as the production of an additional amount of milk requires additional inputs. The available OPV LCA literature (see Section 3) fits the attributional category as it has served to analyze the environmental impacts throughout OPVs life cycle stages. It does not deal with possible changes in demand.

\section{OPV solar cells' environmental profile}

Table 1 provides a chronological || overview of the available LCAs on OPV solar cells. It can immediately be seen from the topic column that polymer photovoltaics have drawn more attention than molecular OPVs and that the field of environmental assessment is heavily dominated by the single-junction bulk heterojunction (BHJ) architecture using a poly(3-hexylthiophene)/[6,6]-phenyl- $\mathrm{C}_{61}$ butyric acid methyl ester or a P3HT/ $\mathrm{PC}_{60} \mathrm{BM}$ blend. $\mathrm{P} 3 \mathrm{HT} / \mathrm{PC}_{60} \mathrm{BM}$ has been a model system in OPVs since it was the first material system to transcend the $5 \%$ efficiency limit. However, recently the number of publications dealing with $\mathrm{P} 3 \mathrm{HT} / \mathrm{PCBM}$ has been surpassed by more efficient systems consisting of a low band gap polymer/PCBM blend. ${ }^{40}$ Consequently, we believe the latter category can now be called the model system, but acknowledge that this is only accurate for low band gap polymers as a family. LCA literature is lagging behind on this shift towards low band gap polymers.

The motivation behind polymer OPVs' current dominance over molecular OPVs can be found in the alleged low energetic and economic cost originating from their solution processability, an advantage that is waning recently as molecular OPVs are also successfully taking advantage of this processing route. ${ }^{44-47}$ Consequently, to avoid having to discuss the majority

॥ On the date of online publication. of the OPV manufacturing chains discussed in LCA literature, we start this section by providing the most frequently used layouts for single-junction BHJ polymer solar cells** (see Fig. 2).

First, a transparent electrode acting as an anode, usually indium-tin-oxide (ITO), is deposited on a substrate. Second, a hole transporting layer (HTL) is coated on top. In most cases poly(3,4-ethylenedioxythiophene):poly(styrenesulfonate)

(PEDOT:PSS) is used, but alternatives $\left(\mathrm{MoO}_{3}, \mathrm{NiO}_{x}, \mathrm{~V}_{2} \mathrm{O}_{5}\right)$ have been identified that overcome its negative side-effects on cell stability. ${ }^{48}$ Then, the active layer (AL) containing the BHJ blend is deposited, which is often followed by an electron transporting layer (ETL). The opposite electrode is the last layer to be deposited. Finally, the whole is sealed off from the environment by lamination. This standard device geometry is shown in Fig. 2, part a. The alternative 'inverted' architecture is shown in part b. This build-up provides a more stable cell configuration by reversing the electrodes. ${ }^{49-51}$ An additional advantage may be found in the ease of processing due to the use of screen printable silver paste as the metal electrode. ${ }^{52}$ Furthermore, it can also be observed from the topic column in Table 1 that semiindustrial processing on pilot lines, mostly in ambient surroundings, has been discussed the most.

The study goals have been divided into two categories, being prospective and retrospective comparison, according to their focus. Prospective studies compare undemonstrated OPVs with demonstrated OPVs or commercially available inorganic PVs. Retrospective studies compare demonstrated OPVs with other demonstrated OPVs or commercially available inorganic PVs. Most studies fall into either one of these categories. Having made this distinction, it should be noted that the majority of studies has assumed lifetimes of fifteen years consistent with the aims of the European Photovoltaic Technology Platform for OPVs by $2013 .^{53}$ Lifetimes of that order of magnitude have however not been confirmed for OPV devices. To the best of our knowledge, it has not reached half of this number. A study by Peters et al. demonstrated a lifetime for PCDTBT (poly $\{[N-$ 9'-heptadecanylcarbazole-2,7-diyl $]$-alt-[5,5-(4',7'-di(2-thienyl)$2^{\prime}, 1^{\prime}, 3^{\prime}$-benzothiadiazole)]\}) devices that approaches 7 years. ${ }^{54}$ Therefore, this commonly made assumption was disregarded for categorization.

As mentioned in the introduction, the life cycle inventory (LCI) data pose a source of uncertainty due to the lack of standardized processing routes and consequently information. Supporting this thesis are the data in Table 2. It shows the ranges of embedded primary energy that can be found or calculated from the provided data in LCA literature for the most frequently used materials. Two key observations can be drawn from tabulating this information. First, a large spread is noticeable for $\mathrm{PC}_{60} \mathrm{BM}$, which is due to the variety of input materials (toluene, tetralin, or graphite) that can be processed using different techniques (pyrolysis and plasma). Pyrolysis is the most used technique for fullerene production. Furthermore, $\mathrm{C}_{60}$ made by pyrolysis of tetralin has been shown to have the lowest embodied energy of $64 \mathrm{GJ}_{\mathrm{p}} \mathrm{kg}^{-1}$. Anctil et al. ${ }^{55}$ have also shown other figures for pyrolysis of toluene to be an

** The term module has also been used to indicate that it is a laminated, finished product. 

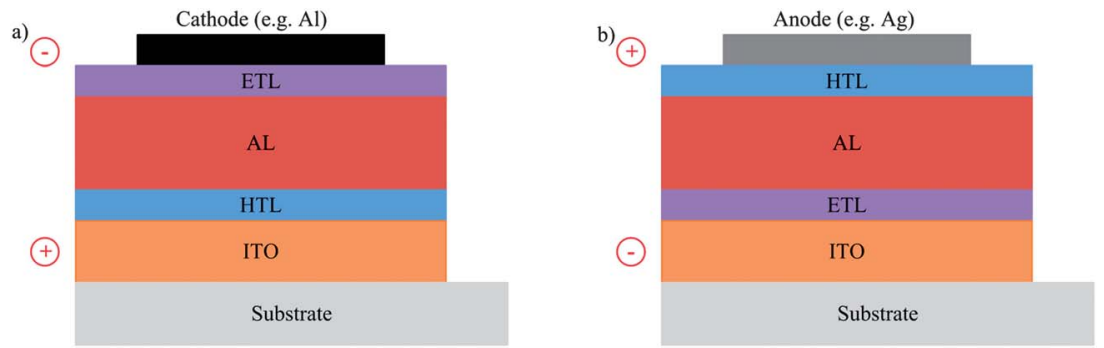

Fig. 2 Cross-section of a standard (a) and an inverted (b) organic polymer solar cell.

Table 2 Input materials' embedded primary energy
Input material

$\mathrm{PC}_{60} \mathrm{BM}$

P3HT

PEDOT:PSS
Embedded primary energy

$[64-125]\left(\mathrm{GJ}_{\mathrm{p}} \mathrm{kg}^{-1}\right)$ [1800-1960] $\left(\mathrm{MJ}_{\mathrm{p}} \mathrm{kg}^{-1}\right)$ $[64-160]\left(\mathrm{MJ}_{\mathrm{p}} \mathrm{kg}^{-1}\right)$ underestimation because they did not account for all four production steps required to obtain useable $\mathrm{PC}_{60} \mathrm{BM}$, being synthesis, separation, purification, and functionalization. Second, a much smaller spread is found for the production of P3HT and PEDOT:PSS. This is due to the quasi-general reliance on the computations made by García-Valverde et al., ${ }^{56}$ which are based on the chemical synthesis techniques called Grignard metathesis for P3HT and oxidative chemical polymerization in aqueous PSS solution for PEDOT:PSS. These are techniques that are used by the main material suppliers providing these inputs, thereby confirming that these materials have a longer industrial history. Fair unanimity was found in the conversion factors used from electrical and thermal energy to primary energy. In the remainder of this section the literature will be further divided into the respective study goals and ranked chronologically.

\subsection{Earlier prospective LCAs}

Undemonstrated OPVs have been granted properties that are not proven, mostly higher efficiencies and higher lifetimes. This type of scenario analysis is employed to both the older ${ }^{56,57}$ and the more recent ${ }^{15,58,59}$ studies. The earlier studies detail laboratory production involving inert atmospheres in more steps than indium tin oxide (ITO) deposition, and aim at comparing such devices with industrially processed modules either on a rigid or flexible substrate. These studies indicate the high promise that flexible OPVs hold having lower environmental impacts on most categories $\dagger \dagger$ compared to multicrystalline silicon (mc-Si) cells and to thin films on the indicators CED, EPBT, and GHG emissions on a Wp or $\mathrm{m}^{2}$ comparison basis. Enabling a fair comparison, th this requires further optimization of both the production process and the product. For the production process

† CED, EPBT, GHG emissions, abiotic depletion, ozone layer depletion, acidification, and eutrophication have been investigated.

t+ Lifetimes are not taken into account using the $\mathrm{m}^{2}$ or $\mathrm{Wp}$ comparison basis. it was shown that ITO sputtering, electrode evaporation, inert atmospheres, and lamination using thermoplastic adhesives are highly energy intensive processes that should be avoided. The same applies to wasteful material deposition techniques such as spincoating that are on the list of not roll-to-roll (R2R) compatible techniques. For the solar cell input materials, it was found that most energy goes into $\mathrm{PC}_{60} \mathrm{BM}$ production. However, direct processing energy outweighs the materials' embedded energy by far. In this regard, it is worth noting that ITO sputtering is thought of as processing energy, while it has also been considered as embedded materials energy seeing that polyethylene terephthalate (PET) sputtered with ITO can readily be bought as a raw material. The assumption of having higher efficiencies is made to show its influence on environmental indicators. Thinking linearly, an increase in lifetime or efficiency improves sustainability in equal proportions. However, no guarantee exists that technology development will be able to fulfill such a relationship. Moreover, in the quest for higher efficiencies it may be necessary to (1) use materials that require more energy to be made or processed and/or (2) to deposit several active material layers instead of a single one. The same logic applies to lifetimes. Better barrier materials do not necessarily improve the EPBT. Consequently, a non-linear relationship involving a trade-off seems plausible.

\subsection{Retrospective LCAs}

Retrospective studies will not detail properties of OPV solar cells, except for lifetime, other than those demonstrated. $\S$ The retrospective studies have picked up and elaborated further upon the recommendations made by the earlier prospective LCAs. Espinosa et al. ${ }^{60}$ have simultaneously introduced R2Rcompatible techniques, ambient atmospheres, and screen printing of the silver electrode using a route called 'ProcessOne'. An EPBT of 1.35-2.02 years could be determined for devices with $2-3 \%$ cell efficiency. Emmott et al. ${ }^{61}$ addressed the substitution of the still present ITO electrode in ProcessOne by solution processable materials, therefore focusing on the energy problem. High conductivity PEDOT:PSS, a silver grid embedded in PEDOT:PSS, silver nanowires, and single wall carbon nanotubes were investigated. They found silver

$\S \S$ Some retrospective studies do contain a sensitivity section but these are disregarded. Only the indicators derived from demonstrated devices are discussed. 
nanowires and high conductivity PEDOT:PSS to be the most promising substitutes. Espinosa et al. ${ }^{62}$ also tried to resolve the ITO problem in ProcessOne by replacing ITO by a sputtered aluminum/chromium layer, thereby zooming in on the scarcity issue surrounding indium. ${ }^{63}$ They ascertained this not to be an energy efficient pathway. Espinosa et $a .^{59}$ have added to the literature by calculating the impact on ProcessOne's sustainability by employing solution processable graphene and graphite electrodes, thereby supplementing the work of Emmott et al. ${ }^{61}$ Significant progress from an environmental perspective vis-à-vis ProcessOne was established for a route called 'Process H', which alters ProcessOne by using a rotary screen printed graphite front electrode and slot die coated silver back electrode. Anctil et al. ${ }^{64}$ have focused on the influence on the device CED by using novel active layer material and tandem structures, for (1) molecular, being vacuum processable $\uparrow \uparrow$ and partly solution processable, |||| and (2) polymer photovoltaics. *** Finally, Espinosa et al. ${ }^{65}$ have added to the literature by scrutinizing the lamination procedure and structure. Further improvements were made by using a cold lamination procedure using pressure sensitive adhesives in combination with a structure consisting of barrier/module/barrier instead of barrier/substrate/module/barrier. Additionally, they have pointed out the importance of technical yields and found inline inspection tools to be a good way to increase this yield. The above details clearly demonstrate the learning capacity of the scientific community.

On the one hand, the ProcessOne route has been incrementally improved, targeting both a lower environmental and economic cost. Frontrunners in this domain are the Danish Risø National Laboratory for Sustainable Energy. ProcessOne's CED has decreased with a factor of about 10 from a three digit (379.26 $\mathrm{MJ}_{\mathrm{p}} \mathrm{m}^{-2}$ ) to a two digit number $\left(37.58 \mathrm{MJ}_{\mathrm{p}} \mathrm{m}^{-2}\right.$ ). Compared to the $2800.79 \mathrm{MJ}_{\mathrm{p}} \mathrm{m}^{-2}$ energy demand when produced in a laboratory, this is a decrease with about a factor of 75. Additionally, the progress made has been projected conservatively seeing the different electricity mixes used. While the first number employed an average European electricity mix of $411.44 \mathrm{~g} \mathrm{CO}_{2}$ eq. $\mathrm{kW}^{-1} \mathrm{~h}_{\mathrm{el}}{ }^{-1}$, most other studies took the Danish electricity mix (420.88 $\mathrm{g} \mathrm{CO}_{2}$ eq. $\mathrm{kW}^{-1} \mathrm{~h}_{\mathrm{el}}{ }^{-1}$ or higher). Simultaneously, the EPBT has gone from years to months by an order of magnitude in spite of low cell efficiencies $(\leq 3 \%)$. For more insight into the calculation of the EPBT indicator, we refer to Yue et $a l .{ }^{58}$ Fair unanimity was found in other parameters influencing the EPBT indicator, with an irradiation of $1700 \mathrm{~kW}$ $\mathrm{h}$ per year per $\mathrm{m}^{2}$ and a performance ratio (PR) of $80 \%$ being used for calculations in most studies. The sole exception is the active area percentage, which varies in the range of $37-67 \%$ for the devices made. With the best performing devices having a relatively low active area $(45.53 \%)$, it can be confirmed that the EPBTs are conservative estimates. This shows the importance of maximizing the usage of the processed area. Analogously, a similar trend is expected for the GHG emissions. However, hard

ฯ I.e. using molecules from the phthalocyanine class.

||| I.e. using molecules from the squaraine class.

*** I.e. using state-of-the-art low bandgap donor-acceptor copolymers. data are lacking in the more recent retrospective publications. Yet, values have been calculated ${ }^{60}\left(37.77 \mathrm{~g} \mathrm{CO}_{2}\right.$ eq. $\mathrm{kW}^{-1} \mathrm{~h}_{\mathrm{el}}{ }^{-1}$ for $3 \%$ efficiency) for the early days ProcessOne, which is comparable to GHG emission factors for commercialized PV technologies (10-50 g CO 2 eq. $\left.\mathrm{kW}^{-1} \mathrm{~h}_{\mathrm{el}}{ }^{-1}\right) .{ }^{27}$ Consequently, this route compares favorably to electricity from coal power plants (900 g $\mathrm{CO}_{2}$ eq. $\mathrm{kW}^{-1} \mathrm{~h}_{\mathrm{el}}^{-1}$ ), natural gas combined cycle plants (439 $\mathrm{g} \mathrm{CO}_{2}$ eq. $\mathrm{kW}^{-1} \mathrm{~h}_{\mathrm{el}}{ }^{-1}$ ), and even nuclear power plants (40 $\mathrm{g}$ $\mathrm{CO}_{2}$ eq. $\left.\mathrm{kW}^{-1} \mathrm{~h}_{\mathrm{el}}{ }^{-1}\right) .{ }^{60}$ Note, however, that both the system degradation rate $(-)$ and the advantage that OPV solar cells have at low irradiance levels $(+)$ were not accounted for.

On the other hand, Anctil et al. ${ }^{64}$ are the sole authors to have researched CED with novel material combinations, $\dagger+\dagger$ both for $\mathrm{BHJ}$ polymer and planar/planar-mixed molecular OPV devices. Among the novel materials, much of their attention has gone to fullerenes. Of all input materials, fullerenes were reconfirmed to have the highest embedded material energy. Furthermore, the more recently introduced $\mathrm{C}_{70}$ requires a considerably higher amount (10-100 $\mathrm{GJ} \mathrm{kg}^{-1}$ order) of embedded energy than $\mathrm{C}_{60}$, both in the native and in the PCBM form. Indene- $\mathrm{C}_{60}$ bisadduct ( $\left.\mathrm{IC}_{60} \mathrm{BA}\right)$ and indene- $\mathrm{C}_{70}$ bisadduct ( $\mathrm{IC}_{70} \mathrm{BA}$ ) have been identified as being promising alternatives for $\mathrm{PC}_{60} \mathrm{BM}$ and $\mathrm{PC}_{70} \mathrm{BM}$. On the one hand, the ranking from the lowest to the highest $\mathrm{CED}$ at the base case is: $\mathrm{IC}_{60} \mathrm{BA}<\mathrm{IC}_{70} \mathrm{BA}<\mathrm{PC}_{60} \mathrm{BM}<\mathrm{PC}_{70} \mathrm{BM}$, with ICBA's CEDs being about 40\% lower than their PCBM counterparts. This reduction is due to a simpler reaction scheme requiring fewer chemicals during synthesis and easier processing compared to PCBM..$^{55,66}$ On the other hand, devices have been made displaying an efficiency of $6.5 \%$ using $\mathrm{IC}_{60} \mathrm{BM}^{67}$ and $7.4 \%$ using $\mathrm{IC}_{70} \mathrm{BA},{ }^{68}$ which is to the best of our knowledge the highest efficiency to date for a device using a blend containing P3HT. Consequently, it has been shown that it is possible to create both more efficient and more eco-friendly and less energy consuming devices than P3HT/PCBM BHJs. Therefore, an increased efficiency need not necessarily imply a higher CED and consequently higher environmental impact. Unfortunately, so far an increase in efficiency using ICBA as the acceptor has only been found in combination with P3HT. More variability exists in the electron donor materials. For polymers, a positive correlation was found between the number of synthesis steps and embedded energy, as is the case for most low bandgap copolymers compared to P3HT. We note that the same applies for cost. ${ }^{69}$ Interface materials such as hole blocking or electron blocking layers were shown to have the lowest embedded materials energy. The CED/Wp for single junction molecular and polymer OPVs spans roughly the same magnitude (3-6 MJ/Wp) with the disadvantage for polymer solar cells of having an on average higher efficiency (5.78\%) than molecular OPVs $(3.83 \%)$ in the present sample. ITO sputtering was confirmed to be typically the most energy consuming for both types of OPVs, followed by the electron acceptor material for polymer OPVs, evaporation for the molecular OPVs, and PET substrate or barrier material for both types of OPVs. For tandem structures, the CED/Wp for polymer solar cells increases

$\dagger \dagger$ All devices nonetheless involve a sputtered ITO and printed silver contact. 
because the gain in efficiency does not outweigh the additional burdens. For molecular devices, the opposite holds. Finally, it has to be noted that solvents have been neglected so far. Anctil et al. ${ }^{64}$ have also pointed out that organic solvents add, but little, to the energy demand. Nevertheless, attention is justified in view of other environmental aspects that may not be (as highly) correlated with the CED.

\subsection{Recent prospective LCAs}

The more recent prospective studies submit Process $\mathrm{H}$ to an indepth scenario and sensitivity analysis.

Espinosa et al. ${ }^{59}$ explored whether it is possible to fulfill the 1 GWp a day challenge we are faced with by manufacturing OPV modules. They answer positively assuming an efficiency of $10 \%$, PR of $80 \%$, irradiation of $1700 \mathrm{~kW} \mathrm{~h}$ per year per $\mathrm{m}^{2}$, an active area of $45 \%$ and lifetime of 1 year. On top of it, it would take very little of our available resources,tt seeing that renewable energy is well suited for powering the manufacture of polymer solar cells. This is a feature distinguishing these cells from competitors owing to their low energy needs, both electrical and thermal. Two scenarios were simulated: (1) the feasible improvements and (2) the challenging improvements. The use of renewable energy, decreasing PET thickness (while maintaining glass-based efficiency ${ }^{70}$ ), increasing the substrate width, using water-based solvents, and increasing the geometric fill factor are considered instantly feasible as they do not require radical innovation. Nevertheless, we feel that some nuance should be added here, as fully aqueous processing is certainly in need of further improvements to fulfill this claim, seeing that it so far leads to a strong loss in efficiency. ${ }^{71}$ The challenging improvements, higher lifetimes, higher efficiencies, multilayer structures, and recycling of materials, do call for innovation. Little insight is given into the contribution of each respective action, except for the increase of efficiencies, but the feasible assumptions decrease EPBTs with about $80 \%$ compared to Process $\mathrm{H}$. The challenging assumptions add an approximately $60 \%$ decline compared to the feasible assumptions. As in previous studies, the assumption of linearity was made while travelling the learning curve. A doubling in efficiency translates into halving the EPBT, which can, but need not be the case, as indicated in Section 3.2. Supposing this assumption holds, EPBTs in the order of days are foretold. Additionally, if a $10 \%$ efficient cell could be made - and this has been done $e^{72,73}$ - and realized using process $\mathrm{H}$, it only needs 26 days to regenerate the energy it consumed during manufacturing without any additional improvements. This means that on this indicator OPVs would outperform even wind power as the best performing renewable energy technology. Additionally, by comparing Process $\mathrm{H}$ to other routes on the Eco-Indicator $99, \S \S \S$ it was confirmed for polymer solar cells that lower CEDs correlate well with lower environmental impacts.

H+ Note that ITO was substituted by a graphite front electrode in Process $\mathrm{H}$. $\S \S \S$ An end-point indicator weighting the environmental impact categories carcinogens, respiratory organics, climate change, ecotoxicity, acidification/eutrophication, land use, minerals, and fossil fuel use.
By means of the Monte Carlo simulation method, Yue et al. ${ }^{58}$ added sensitivity analysis to the more frequently used scenario analysis. Therefore, they are the sole authors to have used a probabilistic approach. This has allowed them to infer the EPBT and GHG emission factor's probability distribution and most influencing parameters for three scenarios being: (1) the current stage, (2) the near-term future (1-2 years), and (3) the long-term future ( 5 years). The power conversion efficiency and the active area percentage are the fixed parameters in each scenario and are increasing with time, respectively from 3 to $8 \%$ and 45 to $85 \%$. A wide distribution results in the current stage. Additionally, it was found that the mean and the standard deviation for both the EPBT and GHG emissions' probability distribution decrease with rising efficiency and active area. Key influencing variables are the cell's efficiency, the PR, and the insolation for the EPBT. The degradation rate completes the list for the GHG emission factor. It should, however, be brought to the readers' attention that the energy embedded in materials and the processing energy remained fixed, representing a selected processing technology. Only transport energy was varied for the parameters residing in the numerator of the EPBT. All parameters in the denominator have been included in the analyses. Consequently, the results might differ if materials' embedded energy and processing energy are allowed to vary, which can be argued. Nevertheless, the authors reconfirmed the potential of future OPV solar cells regarding environmental sustainability.

Lastly, Darling and $\mathrm{You}^{15}$ provide the case for organic photovoltaics in terms of EPBT and GHG emission factor by presenting the outlook (mid and long term) of both Process $\mathrm{H}$ based OPV devices and monocrystalline silicon, polycrystalline silicon, ribbon silicon, and CdTe photovoltaics. They find OPVs to have the lowest EPBT ( $<12$ days) and GHG emission factor (about $10 \%$ of other PV technologies) in the long run, assuming (1) that predicted efficiency increases and embedded energy decreases for the other PV technologies and (2) that it is possible to make a $15 \%$ efficient OPV cell having a lifetime of 20 years with a lower or equal embedded energy of materials and more efficient processing technology than Process $\mathrm{H}$.

\section{Discussion}

This review focuses on profiling the environmental sustainability of OPV solar cells using the following three mid-point LCA indicators: (1) the CED, (2) the EPBT, and (3) the GHG emission factor. Such action is meaningful seeing the fair degree of uniformity in the existing LCA literature. The LCA study's scopes are aligned and most free parameters, such as PR, irradiation, and conversion factors, have been given similar values. Therefore, a transparent view on the evolution of environmental sustainability due to technological progress, from either materials or manufacturing point of view, results for these indicators. Both scientists and policy makers subsidizing OPV research benefit from the key insights discussed in this review.

The result of this review has hinted at semi-industrially manufactured in ambient atmosphere, inverted $\mathrm{P} 3 \mathrm{HT} / \mathrm{PC}_{60} \mathrm{BM} \mathrm{BHJ}$ polymer solar cells' environmental sustainability, seeing that a 
Table 3 Measures covered by LCA

\begin{tabular}{ll}
\hline Materials and device & Manufacturing \\
\hline $\begin{array}{l}\text { Replaced sputtered ITO by rotary screen printed graphite } \\
\text { Removed the PET substrate }\end{array}$ & $\begin{array}{l}\text { Replaced sputtered ITO by rotary screen printed graphite } \\
\text { Removed the PET substrate }\end{array}$ \\
$\begin{array}{l}\text { Used pressure sensitive adhesives } \\
\text { Used pressure sensitive adhesives } \\
\text { Novel electron acceptors }\end{array}$ & $\begin{array}{l}\text { Introduced R2R-compatible manufacturing techniques } \\
\text { Low bandgap electron donors }\end{array}$ \\
Small molecules from the phthalocyanine class $^{a}$ & $\begin{array}{l}\text { Meplaced evaporation of the silver back electrode by printing } \\
\text { Small molecules from the squaraine class }\end{array}$ \\
Tandem structures $^{a}$ & $\begin{array}{l}\text { Increase the active area percentage, keeping other things constant } \\
\text { Increase the technical yield, keeping other things constant }\end{array}$ \\
${ }^{a}$ These measures, related to active layer materials and the device architecture, represent a novel, but minor branch of LCA literature.
\end{tabular}

\section{Evolution of CED $\left(\mathrm{MJp} / \mathrm{m}^{2}\right)$ over time}

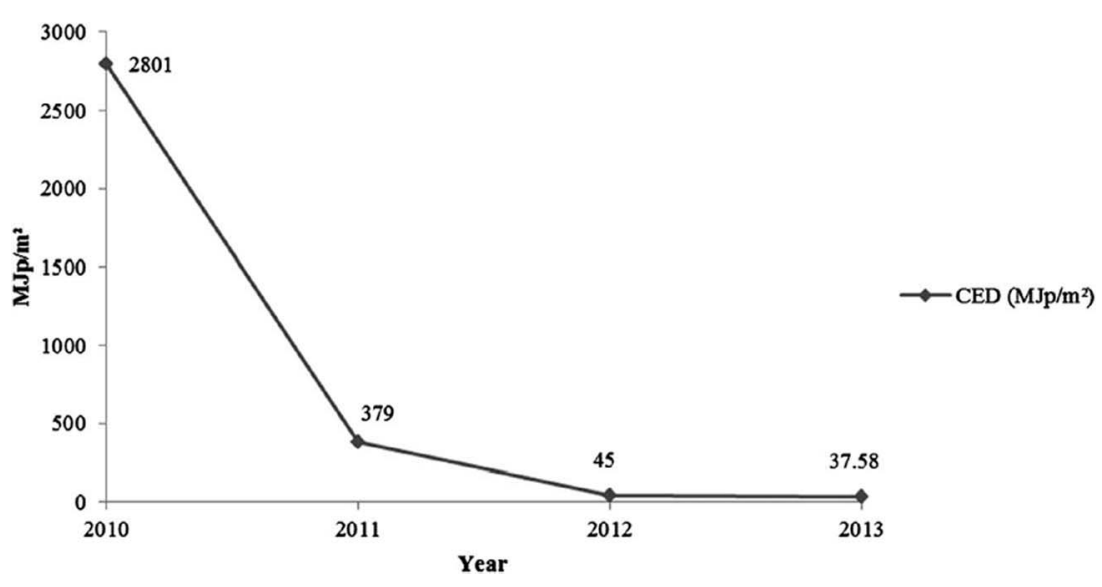

Fig. 3 Evolution of $\mathrm{CED}\left(\mathrm{MJ}_{\mathrm{p}} \mathrm{m}^{-2}\right)$ over time for a $\mathrm{P} 3 \mathrm{HT} / \mathrm{PC}_{60} \mathrm{BM}$ material system.

lower CED was found to translate into lower environmental impacts for many impact categories. ${ }^{56,59}$ Table 3 recapitulates the measures introduced to produce the top performing single-junction $\mathrm{BHJ}$ polymer cell regarding environmental performance. The table shows that, in contradiction to what has been revealed from patent analysis ${ }^{17}$ and meta-analysis, ${ }^{40}$ the main focus has been on manufacturing aspects in LCA literature. Furthermore, it allows stating that the environmental impact has proactively been decreased by technological innovation on the manufacturing side. This has been a smart decision because ITO sputtering, encapsulation, and the deposition of the contacts represent more than half of the CED for single junction OPV devices. A popular option, left uninvestigated in LCA research, is the impact of substituting temperature based annealing $\boldsymbol{\Phi} \uparrow$ by another annealing method or by using additives or other solvents.

Anctil et $a l .{ }^{64}$ are the first to have turned to the advances on the materials' side. Their merit is fourfold. Firstly, they have put the spotlight back upon the high environmental impact of fullerene-based electron acceptors. Their impact was already identified by the oldest LCA studies, but in comparison to electron donors substitutes have been searched for to a far

ๆฯ lesser degree. ${ }^{66}$ Efforts have nevertheless been made to find alternative non-fullerene acceptors. Progress in this field has been reviewed by Sonar et al. ${ }^{74}$ covering both polymers and the underexposed field of small molecules of n-type organic acceptors, and by Facchetti et al. ${ }^{75}$ focusing on polymer acceptors for all-polymer devices. Alternatively, a recent development is to balance the composition of donor-acceptor weight ratios for polymer cells in order to harvest more sunlight while reducing the active layer's thickness. Qian et al. ${ }^{76}$ made a device with high polymer content $(1.5: 1)$ having an efficiency of $6.8 \%$ and $75 \mathrm{~nm}$ thickness, which is radically different from the usual blends, which have ratios varying from $1: 1$ to $1: 4$. Secondly, they have calculated the effect of introducing low bandgap copolymer prototypes (PCDTBT and PTB7) on the CED. Compared to P3HT, they increase the CED, but also increase efficiency by overcoming its large bandgap. ${ }^{77-79}$ However, compared to fullerenes, their impact is still 1 to 2 orders of magnitude lower. Recall that, (a) cells using P3HT/PCBM blends are not the most published system anymore for the polymer cells' active layer, and (b) in the quest for higher efficiencies nowadays low bandgap polymer materials are mainly being used and they increase the CED and by correlation the environmental impact. Thirdly, they are the first to compute the CED for molecular OPV devices. It should however be noted that 
they only discuss partially solution processed molecular OPVs. Fully solution processed $\mathrm{BHJ}$ molecular OPVs remain untouched, but should be assessed as soon as possible seeing the lower energy input required to make small molecules compared to polymers and the high efficiency achieved $(7.16 \%) .{ }^{46}$ Consequently, they are the first attempting to fill in the need for LCI data on new materials. Fourthly, they are the first to assess the CED for polymer and molecular tandem structures. Additionally, the scientific community (physicists, chemists, and engineers) should establish new models that allow predicting OPV cell performance under differing circumstances. At the moment, efficiencies are determined using the standard routine, which for example does not take into account OPVs' advantage at low irradiance levels. Nevertheless, they are not solely responsible for improving future LCA studies. The OPV LCA community is responsible for the transparency of the LCA methodology. Crucial in this regard are the determination of the study's goal and functional unit, the LCA method (attributional or consequential), the system boundaries, and the allocation rules used, which are all interrelated decisions. Additionally, the LCA estimates can be improved (given incomplete databases) by using a hybrid LCI method instead of a process-based method.

Caution when dealing with the above is advised, as the CED is not all-explaining. For instance, the commonly used chlorinated aromatic solvents do not add much to the CED, ||||| but are toxic and hazardous to people who operate manufacturing machines. Therefore, additional guidance towards sustainability is necessary. The 'green chemistry' paradigm, which aims at chemical reaction methodology with minimal production of (toxic) waste at low cost, is one suitable candidate to this end. Applied to novel conjugated polymer materials, five strategies suited for directing large scale synthesis towards greenness have been identified by Burke and Lipomi being: (1) polymerization using metal-mediated cross-coupling reactions that reduce or eliminate stoichiometric organotin waste; (2) the use of heterogeneously catalyzed polymerizations; (3) polymerization involving activation of $\mathrm{C}-\mathrm{H}$ bonds; (4) the use of biofeedstock-derived starting materials; and (5) polycondensation reactions that provide water as a byproduct. ${ }^{\mathbf{8 0}}$ Additionally, inspired by LCA analysis' results, water-based processing has been demonstrated. ${ }^{71,81}$ Another suitable candidate can be found in the wider cradle-to-cradle principle, which essentially strives to create manufacturing systems that are waste-free. Concentrating on the end-of-life, it is crucial to only use components that are biodegradable and/or recyclable. Strange et $a l .{ }^{82}$ have made polymer devices, with unattractive properties so far, using a biodegradable poly-L-lactic acid substrate filled with nanoclay. Zhou et al. ${ }^{83}$ have produced $2.7 \%$ efficient polymer devices**** on a biodegradable cellulose nanocrystal (CNC) substrate, which are fully separable into the main constituents using low-energy processes at room temperature. Note that we explicitly use the word separable, and not

||||| Note that recycling the organic solvents has been disregarded in most LCA studies.

**** The same device on glass has an efficiency of $6.6 \%$. recyclable. No conclusive answer is provided about whether the divided constituents $+\dagger^{\dagger \dagger} \dagger$ can be reused at acceptable cost to build a new, similar solar cell or as input material for other applications. Nevertheless, it is the authors' hope and the current results are thought of as to be opening the door towards a truly fully recyclable solar cell technology, which can be considered a step forward compared to the poor recyclability reported earlier. ${ }^{\mathbf{8 4}}$ If the future would prove them wrong, incineration with heat recuperation and recovery of the metals remains an option. Sadly, in such a case we are burning fullerenes, which for their weight require an enormous amount of energy to produce. ${ }^{85}$ Finally, what if the unavoidable happens and devices do end up in nature? Zimmermann et al. ${ }^{\mathbf{8 6}}$ have found no evidence for a worrying threat coming from $\mathrm{P} 3 \mathrm{HT} /$ $\mathrm{PC}_{60} \mathrm{BM}$ OPV solar cells based on the available information. Further laboratory fate studies are nevertheless thought to be advisable. The threat other OPV solar cell devices pose to the environment remains a gap in risk analysis literature.

From the above, it can be concluded that the LCA literature is not representative of the majority of OPV literature, which uses spincoating on glass substrates to create devices in inert atmospheres with the standard device geometry having a vacuum deposited back electrode, a sputtered ITO front electrode, a spincoated charge transport layer, and a spincoated active layer blend other than $\mathrm{P} 3 \mathrm{HT} / \mathrm{PCBM}^{4}{ }^{\mathbf{4}}$ Nevertheless, it does shape OPVs' environmental profile by demonstrating the learning path any material system should be able to realize. For the learning path that the $\mathrm{P} 3 \mathrm{HT} / \mathrm{PC}_{60} \mathrm{BM}$ has followed on the CED indicator (in $\mathrm{MJ}_{\mathrm{p}} \mathrm{m}^{-2}$ ), see Fig. 3 .

\section{Conclusions}

This paper has reviewed the available attributional LCA literature for organic photovoltaic (OPV) devices. This is a technology found to be residing in the fluid development phase, signaling the community's focus to be product rather than process oriented.

LCA literature's main focus has been on the environmental impact resulting from the materials acquisition and manufacturing life cycle stages of single-junction bulk heterojunction (BHJ) polymer solar cells using a $\mathrm{P} 3 \mathrm{HT} / \mathrm{PC}_{60} \mathrm{BM}$ active layer blend processed on semi-industrial pilot lines in ambient surroundings. Their environmental impact, measured on the indicators cumulative energy demand (CED), energy payback time (ЕРВТ), and greenhouse gas (GHG) emission factor, was found to be decreasing, confirming CED's correlation with other environmental impact categories along the way, through incremental innovation of a manufacturing route called ProcessOne. In contradiction to patent analysis and meta-analysis, the focus has thus been on process innovation. The current top performing cell regarding environmental performance was shown to have a CED of $37.58 \mathrm{MJ}_{\mathrm{p}} \mathrm{m}^{-2}$ and an EPBT in the order of months (3.54-6.24) for cells having $2 \%$ efficiency, ${ }^{55}$ thereby rendering these cells one of the best performing PV

$\dagger+\dagger$ To be clear, these are not all single materials. The active layer is a $\mathrm{BHJ}$ blend of two materials. 
Table 4 Overview of EPBTs of different renewable energy technologies

\begin{tabular}{lll}
\hline $\begin{array}{l}\text { Renewable energy } \\
\text { technology }\end{array}$ & EPBT (years) & Source \\
\hline Biomass combustion & $5-10$ & 49 \\
Biomass gasification & $<5$ & 49 \\
Geothermal & 0.54 & 49 \\
Hydropower & 0.5 & 49 \\
PVs: a-Si & $1.8-3.5$ & 24 \\
PVs: CdTe & $0.75-2.1$ & 24 \\
PVs: CIS & $1.45-2.2$ & 24 \\
PVs: mono-Si & $1.7-2.7$ & 24 \\
PVs: multi-Si & $1.5-2.6$ & 24 \\
PVs: OPVs & $0.29-0.52$ & 55 \\
Wind on land & 0.26 & 49 \\
Wind offshore & 0.39 & 49 \\
\end{tabular}

technologies able to compete with CdTe thin films. Compared to the latter, the top performing polymer solar cells regarding environmental sustainability do not consume scarce materials, as the ITO transparent electrode has been replaced by graphite, showing that the CED is not all-explaining. Additionally, a lower GHG emission factor compared to coal power plants, natural gas combined cycle plants, and even nuclear power plants was found, showing that they are contributing to the sustainable development of our energy production. An overview of how OPVs compare to their renewable substitutes on the EPBT is given in Table 4. Even better results have been foretold by prospective LCA studies.

Product innovation has been identified as being underinvestigated in LCA literature, confirming that it is extremely difficult to obtain the necessary LCI information. The obtained results thus represent an uncertain, rather pessimistic benchmark for fully scaled-up production, but nevertheless they have their value by allowing us to assess the technology's environmental progress. A single paper has been identified that shares the impact on the CED of novel polymer electron donors, novel fullerene electron acceptors, molecular OPVs, and tandem device structures. ${ }^{54}$ Consequently, they are the first to fill in the need for LCI data on new materials. Furthermore, they have shown that the use of low band gap polymer materials and heavier fullerene derivatives, respectively, increases the CED and even the CED/Wp. Therefore, in spite of the scientific community's awareness of the importance of environmental sustainability, the danger exists of it being sacrificed in the quest for higher efficiencies. This proves that the often used linear relationship between both CED and EPBT, and efficiency in scenario analyses does not seem to hold. The former statement also points out that "less will be better" apparently does not apply to the highly energy intensive fullerenes. Nevertheless, it has been proven that higher efficiencies can be reached for particular BHJ blends with materials having a lower CED. Additionally, the scientific community should establish new models that allow predicting OPV cell performance. The OPV LCA community on the other hand is responsible for the transparency of the LCA methodology. Crucial in this regard are the determination of the study's goal and functional unit, the
LCA method, the system boundaries, and the allocation rules used, which are all interrelated decisions. Additionally, the LCA estimates can be improved given incomplete databases by using a hybrid life cycle inventory (LCI) method instead of a processbased method.

In summary, we can conclude that LCA literature is a niche in OPV research not focusing on achieving higher efficiencies and smaller active areas, but on minimizing OPVs' environmental impact while using scalable production techniques. Therefore, we advise the scientific community to take the progress made in this field into consideration not only because standard procedures put a bigger strain on the environment, but also because these methods may not be transferrable to an industrial process. Consequently, we recommend policy makers to subsidize research that bridges the gaps between fundamental materials research, stability, and scalability seeing that these constraints have to be fulfilled simultaneously if OPVs are ever to be successful on the market. Additionally, environmental sustainability will have to keep on being monitored to steer future developments in the right direction.

\section{Acknowledgements}

The authors are much obliged to both the INTERREG ORGANEXT project and FP7 MOLESOL project for their financial support, without which it would have been impossible to conduct this research.

\section{References}

1 R. S. de Groot, M. A. Wilson and R. M. J. Boumans, A typology for the classification, description and valuation of ecosystem functions, goods and services, Ecol. Econ., 2002, 41, 393-408.

2 R. Madlener and S. Stagl, Sustainability-guided promotion of renewable electricity generation, Ecol. Econ., 2005, 53, 147167.

3 European Commission, Directive 2009/28/EC of the European Parliament and of the Council of 23 April 2009 on the promotion of the use of energy from renewable sources and amending and subsequently repealing Directives 2001/77/EC and 2003/30/EC, in, Brussels, 2009, pp. 16-62.

4 T. Tsoutsos, N. Frantzeskaki and V. Gekas, Environmental impacts from the solar energy technologies, Energy Policy, 2005, 33, 289-296.

5 V. V. Tyagi, N. A. A. Rahim, N. A. Rahim and J. A. L. Selvaraj, Progress in solar PV technology: research and achievement, Renewable Sustainable Energy Rev., 2013, 20, 443-461.

6 D. Gebeyehu, B. Maennig, J. Drechsel, K. Leo and M. Pfeiffer, Bulk-heterojunction photovoltaic devices based on donoracceptor organic small molecule blends, Sol. Energy Mater. Sol. Cells, 2003, 79, 81-92.

7 C. J. Brabec, Organic photovoltaics: technology and market, Sol. Energy Mater. Sol. Cells, 2004, 83, 273-292.

8 E. Bundgaard and F. C. Krebs, Low band gap polymers for organic photovoltaics, Sol. Energy Mater. Sol. Cells, 2007, 91, 954-985. 
9 J. Nelson, Polymer:fullerene bulk heterojunction solar cells, Mater. Today, 2011, 14, 462-470.

10 G. Li, R. Zhu and Y. Yang, Polymer solar cells, Nat. Photonics, 2012, 6, 153-161.

11 P. Kumar and S. Chand, Recent progress and future aspects of organic solar cells, Progress in Photovoltaics: Research and Applications, 2012, 20, 377-415.

12 T. D. Nielsen, C. Cruickshank, S. Foged, J. Thorsen and F. C. Krebs, Business, market and intellectual property analysis of polymer solar cells, Sol. Energy Mater. Sol. Cells, 2010, 94, 1553-1571.

13 S. Lizin, S. Van Passel, E. De Schepper and L. Vranken, The future of organic photovoltaic solar cells as a direct power source for consumer electronics, Sol. Energy Mater. Sol. Cells, 2012, 103, 1-10.

14 N. Yeh and P. Yeh, Organic solar cells: their developments and potentials, Renewable Sustainable Energy Rev., 2013, 21, 421-431.

15 S. B. Darling and F. You, The case for organic photovoltaics, RSC Adv., 2013, 3, 17633-17648.

16 R. Dhingra, S. Naidu, G. Upreti and R. Sawhney, Sustainable Nanotechnology: Through Green Methods and Life-Cycle Thinking, Sustainability, 2010, 2, 3323-3338.

17 S. Lizin, J. Leroy, C. Delvenne, M. Dijk, E. De Schepper and S. Van Passel, A patent landscape analysis for organic photovoltaic solar cells: identifying the technology's development phase, Renewable Energy, 2013, 57, 5-11.

$18 \mathrm{~J}$. M. Utterback and W. J. Abernathy, A dynamic model of process and product innovation, Omega, 1975, 3, 639-656.

19 F. C. Krebs, T. Tromholt and M. Jorgensen, Upscaling of polymer solar cell fabrication using full roll-to-roll processing, Nanoscale, 2010, 2, 873-886.

20 F. C. Krebs, T. D. Nielsen, J. Fyenbo, M. Wadstrom and M. S. Pedersen, Manufacture, integration and demonstration of polymer solar cells in a lamp for the "Lighting Africa" initiative, Energy Environ. Sci., 2010, 3, $512-525$.

21 F. C. Krebs, M. Jørgensen, K. Norrman, O. Hagemann, J. Alstrup, T. D. Nielsen, J. Fyenbo, K. Larsen and J. Kristensen, A complete process for production of flexible large area polymer solar cells entirely using screen printing-First public demonstration, Sol. Energy Mater. Sol. Cells, 2009, 93, 422-441.

22 F. C. Krebs, J. Fyenbo, D. M. Tanenbaum, S. A. Gevorgyan, R. Andriessen, B. van Remoortere, Y. Galagan and M. Jorgensen, The OE-A OPV demonstrator anno domini 2011, Energy Environ. Sci., 2011, 4, 4116-4123.

23 Heliatek, EU Commissioner very impressed by her visit to Heliatek, http://www.heliatek.com/newscenter/english-eucommissioner-very-impressed-by-her-visit-to-heliatek/?lang= en\#, 2012, accessed 01 March 2013.

24 F. C. Krebs, Fabrication and processing of polymer solar cells: a review of printing and coating techniques, Sol. Energy Mater. Sol. Cells, 2009, 93, 394-412.

25 B. Ness, E. Urbel-Piirsalu, S. Anderberg and L. Olsson, Categorising tools for sustainability assessment, Ecol. Econ., 2007, 60, 498-508.
26 A. Evans, V. Strezov and T. J. Evans, Assessment of sustainability indicators for renewable energy technologies, Renewable Sustainable Energy Rev., 2009, 13, 1082-1088.

27 J. Peng, L. Lu and H. Yang, Review on life cycle assessment of energy payback and greenhouse gas emission of solar photovoltaic systems, Renewable Sustainable Energy Rev., 2013, 19, 255-274.

28 M. Arena, G. Azzone and A. Conte, A streamlined LCA framework to support early decision making in vehicle development, J. Cleaner Prod., 2013, 41, 105-113.

29 M. Lenzen, Errors in Conventional and Input-Outputbased Life-Cycle Inventories, J. Ind. Ecol., 2000, 4, 127148.

30 R. H. Crawford, Validation of a hybrid life-cycle inventory analysis method, J. Environ. Manage., 2008, 88, 496-506.

31 European Environmental Agency, Energy and environment, Copenhagen, 2008, p. 99.

32 M. A. J. Huijbregts, L. J. A. Rombouts, S. Hellweg, R. Frischknecht, A. J. Hendriks, D. van de Meent, A. M. J. Ragas, L. Reijnders and J. Struijs, Is Cumulative Fossil Energy Demand a Useful Indicator for the Environmental Performance of Products?, Environ. Sci. Technol., 2006, 40, 641-648.

33 J. Jesson, L. Matheson and F. M. Lacey, Doing Your Literature Review: Traditional and Systematic Techniques, SAGE Publications, 2011.

34 T. Ameri, G. Dennler, C. Lungenschmied and C. J. Brabec, Organic tandem solar cells: a review, Energy Environ. Sci., 2009, 2, 347-363.

35 International standards organization, Environmental management - life cycle assessment - principles and framework, in: ISO 14040, 1997.

36 International standards organization, Environmental management - life cycle assessment - goal and scope definition and inventory analysis, in: ISO 14041, 1998.

37 International standards organization, Environmental management - life cycle assessment - life cycle impact assessment, in: ISO 14042, 2000.

38 International standards organization, Environmental management - life cycle assessment - life cycle interpretation, in: ISO 14043, 2000.

39 V. Fthenakis, R. Frischknecht, M. Raugei, H. C. Kim, E. Alsema, M. Held and M. de Wild-Scholten, Methodology Guidelines on Life Cycle Assessment of Photovoltaic Electricity, International Energy Agency Photovoltaic Power Systems Programme, 2011.

40 M. Jørgensen, J. E. Carlé, R. R. Søndergaard, M. Lauritzen, N. A. Dagnæs-Hansen, S. L. Byskov, T. R. Andersen, T. T. Larsen-Olsen, A. P. L. Böttiger, B. Andreasen, L. Fu, L. Zuo, Y. Liu, E. Bundgaard, X. Zhan, H. Chen and F. C. Krebs, The state of organic solar cells-A meta analysis, Sol. Energy Mater. Sol. Cells, 2013, 119, 84-93.

41 G. Finnveden, M. Z. Hauschild, T. Ekvall, J. Guinée, R. Heijungs, S. Hellweg, A. Koehler, D. Pennington and S. Suh, Recent Developments in Life Cycle Assessment, J. Environ. Manage., 2009, 91, 1-21. 
42 M. Thomassen, R. Dalgaard, R. Heijungs and I. Boer, Attributional and consequential LCA of milk production, Int. J. Life Cycle Assess., 2008, 13, 339-349.

43 T. Ekvall and G. Finnveden, Allocation in ISO 14041-a critical review, J. Cleaner Prod., 2001, 9, 197-208.

44 Y. Sun, G. C. Welch, W. L. Leong, C. J. Takacs, G. C. Bazan and A. J. Heeger, Solution-processed small-molecule solar cells with 6.7\% efficiency, Nat. Mater., 2012, 11, 44-48.

45 A. Mishra and P. Bäuerle, Small Molecule Organic Semiconductors on the Move: Promises for Future Solar Energy Technology, Angew. Chem., Int. Ed., 2012, 51, 20202067.

46 J. Zhou, Y. Zuo, X. Wan, G. Long, Q. Zhang, W. Ni, Y. Liu, Z. Li, G. He, C. Li, B. Kan, M. Li and Y. Chen, SolutionProcessed and High-Performance Organic Solar Cells Using Small Molecules with a Benzodithiophene Unit, J. Am. Chem. Soc., 2013, 135, 8484-8487.

47 Y. Lin, Y. Li and X. Zhan, Small molecule semiconductors for high-efficiency organic photovoltaics, Chem. Soc. Rev., 2012, 41, 4245-4272.

48 C. Tao, S. Ruan, G. Xie, X. Kong, L. Shen, F. Meng, C. Liu, $\mathrm{X}$. Zhang, W. Dong and W. Chen, Role of tungsten oxide in inverted polymer solar cells, Appl. Phys. Lett., 2009, 94, 043311.

49 W. Cai, X. Gong and Y. Cao, Polymer solar cells: recent development and possible routes for improvement in the performance, Sol. Energy Mater. Sol. Cells, 2010, 94, 114-127.

50 J.-C. Wang, W.-T. Weng, M.-Y. Tsai, M.-K. Lee, S.-F. Horng, T.-P. Perng, C.-C. Kei, C.-C. Yu and H.-F. Meng, Highly efficient flexible inverted organic solar cells using atomic layer deposited $\mathrm{ZnO}$ as electron selective layer, J. Mater. Chem., 2010, 20, 862-866.

51 F. Zhang, X. Xu, W. Tang, J. Zhang, Z. Zhuo, J. Wang, J. Wang, Z. Xu and Y. Wang, Recent development of the inverted configuration organic solar cells, Sol. Energy Mater. Sol. Cells, 2011, 95, 1785-1799.

52 M. Jørgensen, K. Norrman, S. A. Gevorgyan, T. Tromholt, B. Andreasen and F. C. Krebs, Stability of Polymer Solar Cells, Adv. Mater., 2012, 24, 580-612.

53 European Photovoltaic Technology Platform, A Strategic Research Agenda for Photovoltaic Solar Energy Technology, 2007, p. 76.

54 C. H. Peters, I. T. Sachs-Quintana, J. P. Kastrop, S. Beaupré, M. Leclerc and M. D. McGehee, High eEfficiency Polymer Solar Cells with Long Operating Lifetimes, Adv. Energy Mater., 2011, 1, 491-494.

55 A. Anctil, C. W. Babbitt, R. P. Raffaelle and B. J. Landi, Material and Energy Intensity of Fullerene Production, Environ. Sci. Technol., 2011, 45, 2353-2359.

56 R. García-Valverde, J. A. Cherni and A. Urbina, Life cycle analysis of organic photovoltaic technologies, Progress in Photovoltaics: Research and Applications, 2010, 18, 535-558.

57 A. L. Roes, E. A. Alsema, K. Blok and M. K. Patel, Ex-ante environmental and economic evaluation of polymer photovoltaics, Progress in Photovoltaics: Research and Applications, 2009, 17, 372-393.
58 D. Yue, P. Khatav, F. You and S. B. Darling, Deciphering the uncertainties in life cycle energy and environmental analysis of organic photovoltaics, Energy Environ. Sci., 2012, 5, 91639172.

59 N. Espinosa, M. Hosel, D. Angmo and F. C. Krebs, Solar cells with one-day energy payback for the factories of the future, Energy Environ. Sci., 2012, 5, 5117-5132.

60 N. Espinosa, R. García-Valverde, A. Urbina and F. C. Krebs, A life cycle analysis of polymer solar cell modules prepared using roll-to-roll methods under ambient conditions, Sol. Energy Mater. Sol. Cells, 2011, 95, 1293-1302.

61 C. J. M. Emmott, A. Urbina and J. Nelson, Environmental and economic assessment of ITO-free electrodes for organic solar cells, Sol. Energy Mater. Sol. Cells, 2012, 97, 14-21.

62 N. Espinosa, R. García-Valverde, A. Urbina, F. Lenzmann, M. Manceau, D. Angmo and F. C. Krebs, Life cycle assessment of ITO-free flexible polymer solar cells prepared by roll-to-roll coating and printing, Sol. Energy Mater. Sol. Cells, 2012, 97, 3-13.

63 European Commission, Critical raw materials for the EU: Report of the ad-hoc working group on defining critical raw materials, Brussels, 2010, p. 84.

64 A. Anctil, C. W. Babbitt, R. P. Raffaelle and B. J. Landi, Cumulative energy demand for small molecule and polymer photovoltaics, Progress in Photovoltaics: Research and Applications, 2012, DOI: 10.1002/pip.2226.

65 N. Espinosa, F. O. Lenzmann, S. Ryley, D. Angmo, M. Hosel, R. R. Søndergaard, D. Huss, S. Dafinger, S. Gritsch, J. M. Kroon, M. Jorgensen and F. C. Krebs, OPV for mobile applications: an evaluation of roll-to-roll processed indium and silver free polymer solar cells through analysis of life cycle, cost and layer quality using inline optical and functional inspection tools, J. Mater. Chem. A, 2013, 1, 7037-7049.

66 Y. He, H.-Y. Chen, J. Hou and Y. Li, Indene-C60 Bisadduct: A New Acceptor for High-Performance Polymer Solar Cells, J. Am. Chem. Soc., 2010, 132, 1377-1382.

67 G. Zhao, Y. He and Y. Li, 6.5\% Efficiency of Polymer Solar Cells Based on Poly(3-hexylthiophene) and Indene-C60 Bisadduct by Device Optimization, Adv. Mater., 2010, 22, 4355-4358.

68 X. Guo, C. Cui, M. Zhang, L. Huo, Y. Huang, J. Hou and Y. Li, High efficiency polymer solar cells based on poly(3-hexylthiophene)/indene-C70 bisadduct with solvent additive, Energy Environ. Sci., 2012, 5, 7943-7949.

69 T. P. Osedach, T. L. Andrew and V. Bulovic, Effect of synthetic accessibility on the commercial viability of organic photovoltaics, Energy Environ. Sci., 2013, 6, 711-718.

70 M. Kaltenbrunner, M. S. White, E. D. Głowacki, T. Sekitani, T. Someya, N. S. Sariciftci and S. Bauer, Ultrathin and lightweight organic solar cells with high flexibility, Nat. Commun., 2012, 3, 770-776.

71 R. Søndergaard, M. Helgesen, M. Jørgensen and F. C. Krebs, Fabrication of Polymer Solar Cells Using Aqueous Processing for All Layers Including the Metal Back Electrode, Adv. Energy Mater., 2011, 1, 68-71. 
72 M. A. Green, K. Emery, Y. Hishikawa, W. Warta and E. D. Dunlop, Solar cell efficiency tables (version 42), Progress in Photovoltaics: Research and Applications, 2013, 21, 827-837.

73 NREL, Best research-cell efficiencies, http://www.nrel.gov/ ncpv/images/efficiency_chart.jpg, 2013, accessed 03 August 2013.

74 P. Sonar, J. P. F. Lim and K. L. Chan, Organic non-fullerene acceptors for organic photovoltaics, Energy Environ. Sci, 2011, 4, 1558-1574.

75 A. Facchetti, Polymer donor-polymer acceptor (all-polymer) solar cells, Mater. Today, 2013, 16, 123-132.

76 D. Qian, W. Ma, Z. Li, X. Guo, S. Zhang, L. Ye, H. Ade, Za. Tan and J. Hou, Molecular Design toward Efficient Polymer Solar Cells with High Polymer Content, J. Am. Chem. Soc., 2013, 135, 8464-8467.

77 H.-Y. Chen, J. Hou, S. Zhang, Y. Liang, G. Yang, Y. Yang, L. Yu, Y. Wu and G. Li, Polymer solar cells with enhanced open-circuit voltage and efficiency, Nat. Photonics, 2009, 3, 649-653.

78 Y. Liang, Z. Xu, J. Xia, S.-T. Tsai, Y. Wu, G. Li, C. Ray and L. Yu, For the Bright Future-Bulk Heterojunction Polymer Solar Cells with Power Conversion Efficiency of 7.4\%, Adv. Mater., 2010, 22, E135-E138.

79 H. Zhong, Z. Li, F. Deledalle, E. C. Fregoso, M. Shahid, Z. Fei, C. B. Nielsen, N. Yaacobi-Gross, S. Rossbauer, T. D. Anthopoulos, J. R. Durrant and M. Heeney, Fused Dithienogermolodithiophene Low Band Gap Polymers for
High-Performance Organic Solar Cells without Processing Additives, J. Am. Chem. Soc., 2013, 135, 2040-2043.

80 D. J. Burke and D. J. Lipomi, Green chemistry for organic solar cells, Energy Environ. Sci., 2013, 6, 2053-2066.

81 T. R. Andersen, T. T. Larsen-Olsen, B. Andreasen, A. P. L. Böttiger, J. E. Carlé, M. Helgesen, E. Bundgaard, K. Norrman, J. W. Andreasen, M. Jørgensen and F. C. Krebs, Aqueous Processing of Low-Band-Gap Polymer Solar Cells Using Roll-to-Roll Methods, ACS Nano, 2011, 5, 4188-4196.

82 M. Strange, D. Plackett, M. Kaasgaard and F. C. Krebs, Biodegradable polymer solar cells, Sol. Energy Mater. Sol. Cells, 2008, 92, 805-813.

83 Y. Zhou, C. Fuentes-Hernandez, T. M. Khan, J.-C. Liu, J. Hsu, J. W. Shim, A. Dindar, J. P. Youngblood, R. J. Moon and B. Kippelen, Recyclable organic solar cells on cellulose nanocrystal substrates, Sci. Rep., 2013, 3, 1536-1540.

84 L. Reijnders, Design issues for improved environmental performance of dye-sensitized and organic nanoparticulate solar cells, J. Cleaner Prod., 2010, 18, 307-312.

85 H. C. Kim and V. Fthenakis, Life Cycle Energy and Climate Change Implications of Nanotechnologies, J. Ind. Ecol., 2013, 17, 528-541.

86 Y.-S. Zimmermann, A. Schäffer, C. Hugi, K. Fent, P. F. X. Corvini and M. Lenz, Organic photovoltaics: potential fate and effects in the environment, Environ. Int., 2012, 49, 128-140. 